School of Economics and Business Administration

\title{
DOES CORRUPTION HINDER FIRM ENERGY EFFICIENCY? EVIDENCE FROM VIETNAM
}

Gaygysyz Ashyrov, Helen Poltimäe 
ISSN-L 1406-5967

ISSN 1736-8995

ISBN 978-9985-4-1288-6 (pdf)

The University of Tartu FEBA

https://majandus.ut.ee/en/research/workingpapers 


\title{
Does corruption hinder firm energy efficiency? Evidence from Vietnam.
}

\author{
Gaygysyz Ashyrov, Helen Poltimäe*
}

\begin{abstract}
Energy efficiency is an important issue for developing countries like Vietnam, where the economy is thriving, but energy efficiency is still low. Firms should invest in energy efficiency measures, but the desired level is not reached. While the economic determinants of firms' investments in energy efficiency have been researched, the role of the institutional setting has not gained so much attention. By employing data from Vietnamese small and medium-sized enterprises that has been administered in 2015, this article investigates how corruption, as a sign of institutional dysfunctionality, is associated with the energy efficiency in firms. Results of a bivariate binary probit estimation revealed that bribery increases the likelihood of energy efficiency environmentally friendly investments. However, findings from instrumental variable two stage least squares estimations demonstrate that bribery increases the cost of the investments. Hence, in the long run, corruption might have a deterring effect on energy efficiency investments by firms.
\end{abstract}

JEL Classification: D73, O13, O17, P28

Keywords: corruption, energy efficiency, institutional setting, Vietnam.

\footnotetext{
* Gaygysyz Ashyrov, PhD, School of Economics and Business Administration, University of Tartu, Estonia. Address: Narva Road 18, 51009 Tartu, Estonia.

E-mail: ashyrov@ut.ee. Orcid: 0000-0003-1770-8120

Helen Poltimäe, PhD, School of Economics and Business Administration, University of Tartu, Estonia. Address: Narva Road 18, 51009 Tartu, Estonia. E-mail: helen.poltimae@ut.ee.

Gaygysyz Ashyrov acknowledges support from the Estonian Research Council's research project PRG791 Innovation Complementarities and Productivity Growth and financial support from the European Union's Horizon 2020 research and innovation programme under grant agreement No. 822781 GROWINPRO -Growth Welfare Innovation Productivity.
} 


\section{INTRODUCTION}

Environmental issues have attracted more and more attention, very often triggered by the debate about climate change. Climate change is closely related to the energy sources used and the efficiency of that use. Typically, increased energy use accompanies economic growth, specifically in the case of developing countries. Vietnam, a Southeast Asian transition country, has been presenting high economic growth rates: in the past 10 years it has been between $5.3 \%$ and 7\% annually (General Statistics Office of Vietnam, 2020). High industrial growth, rapid urbanisation and population growth require vast energy supplies (Luong, 2015). Low energy efficiency has been a crucial energy issue in Vietnam, caused by the existing use of old technologies and equipment and poor energy management (Luong, 2015). Government and industry representatives encourage firms to make investments in energy efficient technologies and implement energy efficiency measures, as these could be considered important steps towards to sustainable production. Energy efficiency investments have been acknowledged as important environmental investments that could contribute to all three aspects - the triple bottom line - of a sustainable manufacturing framework encompassing the economic, environmental and societal aspects of energy use in manufacturing (Bunse et al., 2011, Hrovatin et al., 2016).

To achieve this goal, it is important to identify the main factors that facilitate firm-level energy efficiency investments or deter them. Several studies have concentrated on the drivers, such as competition, innovation and opportunity to realise the long-term benefits (Cagno and Trianni, 2013), high energy costs (Thollander and Ottosson, 2008) and public financing of technologies (Kounetas \& Tsekouras, 2008) (for a systematic review of drivers, see Solnørdal \& Foss, 2018). On the other hand, Fresner et al. (2017) have revealed barriers to energy efficiency in small and medium-sized enterprises, such as limited access to capital and information, limited internal skills, lack of energy audits, lack of competence building (for other barriers, see Rohdin \& Thollander, 2006; Trianni and Cagno, 2012; Wang et al., 2018). However, most of these studies aiming to understand the determinants and underpinnings of the adoption of energy efficient technologies, have primarily focused on the economic factors related to firm or industry-related characteristics and features. However, a firm's intention to make energy efficient and environmentally friendly investments may also be dependent on other factors, such as various regulations (Kounetas \& Tsekouras, 2008) and the institutional setting (Vatn, 2020).

Governments introduce environmental regulations and reforms to support firms wanting to make energy efficiency investments and to encourage firms to upgrade their production system towards cleaner and more environmentally friendly production. Although legislation increases the general environmental awareness of SMEs (Gadenne et al., 2009), there could be difficulties in accomplishing the desired levels of energy saving and cleaner production due to mainly institutional weaknesses. Better institutions could facilitate the implementation of the regulations set by governments (Acemoglu et al., 2003). For example, tough environmental policies in Central and Eastern European countries led to a decrease in $\mathrm{CO} 2$ emissions in the late 1990s and early 2000s and this is partly explained by institutional factors (Zugravu et al., 2008; Galinato \& Chouinard, 2018). Corruption, a sign of a poor institutional setting and a consequence of institutional dysfunctionality, may result in less stringent environmental policies (Damania et al., 2003; Fredriksson et al., 2003; Pellegrini and Gerlagh, 2006; Woods, 2008). Fredriksson and Svensson (2003) assert that corruption and political instability jointly impact environmental regulation stringency, and corruption may weaken the stringency of the environmental regulations and law enforcement. 
Given the context described above, we argue that corruption, as an indicator of institutional weakness, could be related to the firm's decision to invest less in energy efficient equipment because corruption weakens the enforcement of the environmental regulations and law (Aklin et al., 2014). Therefore, this paper aims to investigate the role of corruption in small and mediumsized enterprises (SMEs) to engage in energy efficient investments. Apart from the considerable economic contribution of SMEs, they are also assumed to be responsible for around $60 \%$ of carbon dioxide emissions and 70\% of all pollution (Revell and Blackburn, 2007; Parker et al., 2009). In addition, it has been demonstrated that SMEs need more assistance in developing sustainable business models, as their practices are different from larger firms (Dillard et al., 2010). Consequently, SMEs are quite relevant for an analysis of the link between corruption and energy efficiency. To our knowledge, this is the first effort to examine the link between corruption and SMEs adoption of and engagement in energy efficient investments.

This paper makes use of a Vietnamese survey of SMEs conducted in 2015. The survey covers 2,467 firms from ten provinces and presents rich details and sets of information about, among others, financial indicators, employment, innovation activities and environment related investments. In terms of methodology, we have divided the analysis into two steps. In the first step, by using a bivariate probit model, we estimate together models of investments in energy efficiency as environmentally friendly investments (EFI) and the process of obtaining certificates verifying the satisfaction of environmental standards (ESC) in Vietnam. In this way, we can observe how the probability of paying a bribe is related to the likelihood of making EFIs and obtaining ESCs. There could be a correlation between unobservable factors linked to both variables, EFI and ESC. In the second step, we employ instrumental variable two stage least squares to study the linkage between bribery and the cost of investments in energy efficiency. There could be several empirical concerns, such as omitted variable bias and reverse causality, when analysing the relationship between corruption and the cost of firms' environmental investments.

\section{BACKGROUND}

Vietnam has been presenting high economic growth rates: in past 10 years it has been between 5.3\% and 7\% annually (General Statistics Office of Vietnam, 2020) and around 45\% of GDP is contributed by SMEs (OECD, 2018). While GDP has grown considerably, energy efficiency does not show improvement: the amount of $\mathrm{CO} 2$ produced per GDP unit has even increased from $0.2 \mathrm{~kg}$ of $\mathrm{CO} 2$ per GDP unit in 1995 to $0.35 \mathrm{CO} 2$ per GDP unit in 2017 (International Energy Agency, 2020). Other concerns about the environment and pollution are also emerging. According to the Environment Performance index, Vietnam is ranked 132 out 180 , specifically poor in air quality and air pollution, for which Vietnam belongs to the worst $15 \%$ of countries. With increasing economic output, the environmental problems also increase, and to decrease these hazards but still maintain economic growth in Vietnam investments that address environmental problems are inevitable (Trinh \& Quoc, 2017). Still, research regarding environmental issues and their relationship to various institutional and economic factors is limited or even missing about Vietnam. Most of the related studies in Asia are about China: for example, how the environmental regulation system affects ecoefficiency (Ren et al., 2018), how to address the environmental pollution accompanying economic growth (Gao et al., 2010), the economic threshold of effective environmental 
regulation (Pang et al., 2019), and policy instruments to assist the transfer to a low-carbon economy (Wang \& Chang, 2014). However, as the institutional and development context are so different, the attained knowledge cannot be transferred to other countries.

Similar studies about Vietnam are much scarcer. Tarras-Wahlberg and Nguyen (2008) highlight the inadequate capacity of public authorities in terms of environmental surveillance, but also the lack of awareness of environmental legislation, which has caused adverse environmental impacts locally. At the same time, it has been demonstrated that large societal changes in Vietnam characteristic to a transitional country, such as urbanisation and economic growth have contributed to environmental degradation in terms of several air pollutants like $\mathrm{CO} 2, \mathrm{CH} 4$ and NO (Fan et al., 2019). Further studies have also demonstrated that economic growth, specifically through foreign direct investments, lead to increasing fossil fuel consumption and greenhouse gases, as the environmental standards are lower in Asian countries compared to developed countries (Hanif et al., 2019).

To date, there are few studies that have investigated the association between corruption and firm environmental investments. To our best knowledge, no research has been done in the context of Vietnam. In particular, Vietnam presents valuable insights for this research and combines many features of transition countries. The high growth rates and transition period generates more opportunities for corrupt behaviour (Tromme, 2016). Transparency International publishes the Corruption Perception Index (CPI) which provides a general picture of the corruption level in countries around the world. According to the CPI, Vietnam is ranked 117 out of 180 countries with a score of 33 out of 100 points (where a higher score means less corruption) in 2018. Widespread corruption has influenced individuals and businesses in Vietnam (Ashyrov, 2020). Since corruption has evolved as "the way of doing business" or "the rules of the game" in Vietnam, firms tend to get involved in corrupt activities (Nguyen et al., 2016). To obtain public services in Vietnam, firms are expected to transfer informal payments or bribes (Rand and Tarp, 2012). For example, around 23\% of firms in Vietnam pay bribes for registration, and approximately $35 \%$ of firms make informal payments when attempting to secure government procurement contracts (Gueorguiev and Malesky, 2012). 


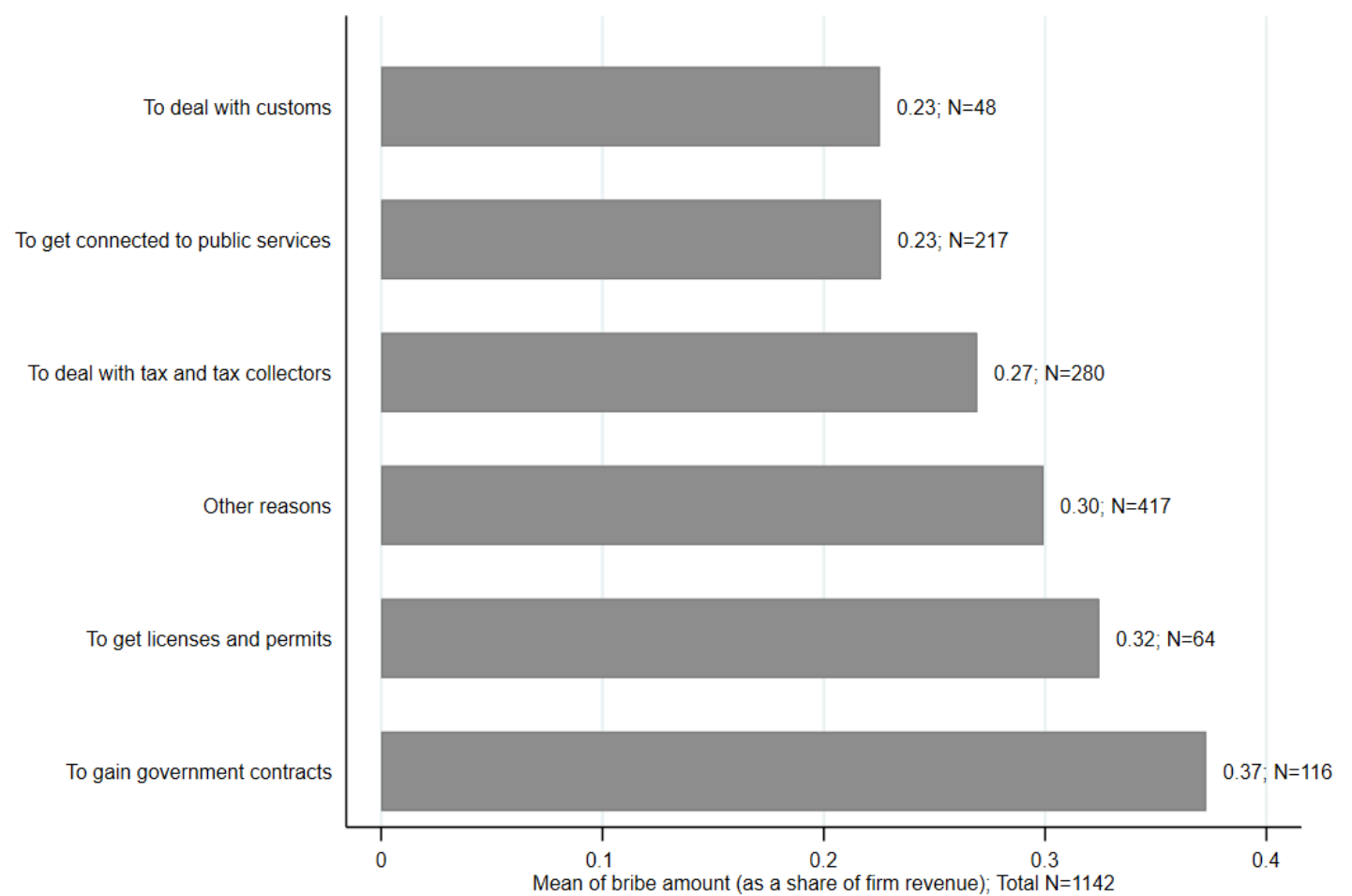

Figure 1: Bribe purposes and amount of bribe. Source: Compiled by authors based on the survey dataset used in empirical analysis.

In Figure 1, we have plotted the purposes of bribes and the average size of the bribe paid. First, the largest share of firms, 417 firms out of 1,142, pay informal payments for other reasons, while the second largest share, 280 out of 1,142 , pays bribes to deal with tax and tax collectors. Furthermore, firms pay bribes to secure government contracts and licences and permits, on average, $0.37 \%$ and $0.32 \%$ of their revenue, respectively.

The rational choice theory of Becker (1968) may help us to delve the relationship between firm's tendency to commit corruption and make environmentally friendly investments. According to this theory, managers or firms tend to get involved in crime if their expected benefit exceeds the gains from alternative lawful practices. Falling within the scope of our paper, this theory implies that the expected benefit of paying a bribe should be greater than the combination of both the likelihood of being caught by non-corrupt officials and the expected cost of a penalty which includes penalties for violating environmental regulations. In addition, the tendency among firms or entrepreneurs to engage in corrupt practices is also driven by the chance that the corruption will be successful (Dickel and Graeff, 2018). Therefore, we can say that individuals or firms could pay bribes to public officials once they calculate the consequences of paying bribes instead of allocating resources to environmentally friendly investments and are confident on that corruption is more likely to be successful.

A great deal of previous studies (e.g., Fredriksson and Svensson, 2003) have demonstrated that corruption may have adverse impacts on the environment. For example, corruption could increase emissions directly by reducing the stringency of environmental regulations and weakening their enforcement (e.g. Aklin et al., 2014). Corruption also impacts emissions indirectly through its effect on per capita income (Cole, 2007). Likewise, corruption could help manufacturing firms avoid environmental regulations by having special relationships with public officials, thereby reducing the effectiveness of the regulations (Sheng, 2019). 
Despite the short-term benefits of these illegal interactions between firms and public officials, it may have more costly consequences on operations in the long term.

A much-debated question is whether corruption has a sand the wheel or a grease the wheel effect on firms (e.g. Méon and Sekkat, 2005). The former effect is meant as the adverse effect of corruption on firm performance (see e.g. Mauro, 1995; Fisman and Svensson, 2007, Ashyrov \& Masso, 2020). According to this view, corruption could function as a tax on SME profitability via increasing loan costs (Wellalage et al., 2019), limiting their ability to operate efficiently and reducing the incentives for firms to invest (Harstad and Svensson, 2011; Van $\mathrm{Vu}$ et al., 2018). O'Toole and Tarp (2014) have revealed that bribery reduces investment efficiency and domestic small and medium-sized enterprises suffer the most from these adverse effects. Since corruption diminishes the marginal return per unit of investment, the cost of bribe payments deteriorates the efficient allocation of capital. On the other hand, the grease the wheel effect is attributed to the positive effect of corruption on firm operations. Corruption could be a tool for overcoming bureaucratic rigidities and increasing firm efficiency in countries where the institutional setting is poor and functions ineffectively. This could also be linked to the view of the Asian paradox. This paradox was postulated by Kaufmann and Wei (1999, p. 10), saying that "corruption has been part of the Asian culture for a long time and does not seem to hamper business there".

\section{DATA AND METHODOLOGY}

\subsection{Data}

This paper employs data on Vietnamese small and medium-sized enterprises that has been collected in 2015 based on face-to-face interviews (survey questionnaire) with firm representatives (owners/managers) of manufacturing enterprises in Vietnam. The data covers nine Vietnamese provinces: Hanoi (including Ha Tay), Hai Phong, Ho Chi Minh City, Phu Tho, Nghe An, Quang Nam, Khanh Hoa, Lam Dong, and Long An. This survey dataset is rich in information about firms, including enterprise history, production characteristics and technology, employment, business and governance, firm performance (e.g. sales, indirect costs, raw materials and services), firm networks, the background characteristics of the owner or manager, and financial indicators (i.e. revenues, costs, assets and liabilities). Two data sources from the General Statistics Office of Vietnam (GSO): (i) the 2002 Establishment Census and; (ii) the 2004-06 Industrial Survey, have been used to determine the population of non-state manufacturing enterprises in the abovementioned provinces. Stratified sampling was employed to confirm an adequate number of firms in each province with different ownership forms such as household enterprises, sole proprietorships, partnerships, limited liability, and joint stock enterprises (Sharma \& Tarp, 2018).

\subsection{Variables}

We divide dependent variables into two categories: first, binary variables that show whether a firm engages in EFI. EFI consists of three different energy efficiency measures: fire, heat, and light. Each of these three EFI measures takes the value 1 if the firm reported YES and 0 otherwise. Second, continuous variables that demonstrate the size of the EFI cost. We gauge 
corruption by using two different questions. The first variable, binary variable bribe, was elicited by using information about whether the firm has to pay informal/communication fees (equals 1 if yes; otherwise equals 0 ). The second variable, amount of bribe or bribe intensity, measures the amount of these informal/communication fees paid by the enterprise. The respondents were asked: “Approximately how much did you pay in total in 2014?" The bribe amount, which can be considered a firm-specific bribery cost/expenditure, directly associates the impact of bribery in monetary terms with the firm's cost of EFI measures. This conforms the suggestions provided in previous studies (see e.g. O'Toole and Tarp, 2014; Reinikka and Svensson, 2006) and is similar to the corruption measure in Ashyrov (2020). (Descriptions are provided in Appendices, Table 1A)

Following the empirical literature on the determinants of firms adopting and investing in energy efficiency or clean technologies (see e.g. Hrovatin et al., 2016), we have added various independent variables to our models as follows. Respondent characteristics form three dummy variable for gender (coded 1 if male, 0 otherwise), respondent's self-reported knowledge of the law (coded 1 if they reported good or average, 0 for poor or no knowledge), education (coded 1 if at least college educated; 0 otherwise), and age (in years). To capture other characteristics of the firm that could impact the EFI decision, we added additional firm-level control such as firm size (measured by number of employees), whether it is a household enterprise (takes value 1 if yes; 0 otherwise), age of firm (in years), whether the firm faces competition (takes value 1 if yes, 0 if no), whether the firm makes positive R\&D investments (takes value 1 if yes, 0 if no), export, whether firm has a positive export (takes value 1 if yes, 0 if no), debt ratio (DR), return on assets (ROA), self-reported major constraints on growth (coded 1 if shortage of capital, 0 otherwise). In addition, to control for sector specific effects, we have included sector dummies. Lastly, to capture the cross-province variation in institutional quality, we have added provincial institutional quality indexes from the Vietnam Provincial Competitiveness Index (PCI_score) in 2015.

We design our research methodology by focusing on different stages of environmental investment decisions in firms. Hence, we now turn to the results of the econometric analysis in the two steps by utilising two different estimation techniques: (i) bivariate probit technique, and (ii) instrumental variable two stage least squares (IV 2SLS) methods. We assume that firms need a "certificate for registration of satisfaction of environmental standards (ESC)". Therefore, we have also created a binary variable that indicates whether firms hold an ESC. SMEs in countries where corruption is widespread could prefer to be a compliant firm and invest in EFI. At the same time, along with EFI, they could also obtain an ESC to avoid furthering extortion. Therefore, managers may simultaneously make decisions in favour of EFI measures and an ESC for the purpose of maximising benefits subject to the corruption demands of public officials. Accordingly, in the first stage, this paper jointly models EFI and obtaining an ESC in Vietnam. In this way, we can observe how the probability of paying a bribe is related to the likelihood of investing in EFI and obtaining an ESC. There could be a correlation between the unobservable factors linked to both variables, EFI and ESC. To address this concern, we have employed a bivariate probit model, where both EFI measures and ESC are estimated according to the same set of independent variables, and the correlation between the two error terms of EFI and ESC is estimated as an auxiliary parameter. Since the bivariate probit maximum likelihood model has a nonlinear nature, the coefficients from estimations may not be interpreted as straightforwardly as with linear models (Yildirim and Dal, 2016). Therefore, we will present marginal effects in order to interpret coefficients and sizes. 
The IV 2SLS estimation strategy will be used to predict the cost of environmental investments conditional on bribes paid by firms to public officials. This estimation strategy will enable us to address potential endogeneity between EFI and bribe amount. Here, it is crucial to find adequate instrument(s) which should be correlated with bribe intensity but not with EFI cost measures. We have selected three different instruments for each model of EFI cost variables and bribe amounts. First, for the cost of fire related investments, we used a survey question: "Approximately, what percentage of the management's working time is spent each month dealing with government regulations and officials (including taxes, permits, licences, business and trade regulations)?" and denoted this variable as time tax. Similar variables have been used by De Rosa et al. (2015). This variable is expected to correlate with the bribe amount or bribe intensity, since more time spent with government officials means more red tape; more red tape may lead to higher levels of corruption (Mauro, 1995) - in our case, larger bribes paid. The second instrument for the model of bribe amount and for the cost of heating related investments comes from the survey question: "How many times in 2012 did your contacts (politicians and civil servants) assist in issues related to the operation of your firm?" This instrument is likely to be correlated with bribes, since firms tend to pay informal payments to overcome regulations by using political contacts or civil servants in corrupt countries (Nguyen, 2016). The last instrument for bribe amount in estimating the cost of lighting is the province-sectoral average of bribe frequency (Only once (1), 2-5 times (2), 6-10 times (3), More than 10 times (4)). Bribes as an expense are likely to be affected by rival firms in the same sectors and provinces.

\section{Table 1. Summary Statistics}

\begin{tabular}{lccccc}
\hline & $\mathrm{N}$ & Mean & SD & Min & Max \\
\hline Respondent characteristics & & & & & \\
Male (\%) & 2647 & 0.59 & 0.49 & 0 & 1 \\
Respondent age & 2647 & 46.42 & 11.13 & 21 & 89 \\
College (\%) & 2647 & 0.27 & 0.44 & 0 & 1 \\
Law knowledge (\%) & 2647 & 0.17 & 0.38 & 0 & 1 \\
Firm characteristics & & & & & \\
Firm size & 2647 & 16.02 & 37.82 & 1 & 700 \\
Age & 2645 & 16.50 & 10.13 & 2 & 61 \\
Household (\%) & 2647 & 0.63 & 0.48 & 0 & 1 \\
Competition (\%) & 2647 & 0.88 & 0.33 & 0 & 1 \\
R \& D investment (\%) & 2647 & 0.52 & 0.50 & 0 & 1 \\
Export (\%) & 2615 & 0.07 & 0.26 & 0 & 1 \\
Debt Ratio & 2647 & 0.09 & 0.24 & 0 & 6.17 \\
Return on assets (ROA) & 2647 & 0.62 & 1.27 & -0.34 & 31.77 \\
Shortage of capital & 2647 & 0.18 & 0.39 & 0 & 1 \\
Firm environmental variables & & & & & \\
Investments in equipment for: Fire (\%) & 2647 & 0.37 & 0.48 & 0 & 1 \\
Investments in equipment for: Heat (\%) & 2647 & 0.24 & 0.43 & 0 & 1 \\
Investments in equipment for: Lighting (\%) & 2647 & 0.21 & 0.41 & 0 & 1 \\
Cost of equipment for: Fire (1,000 VND) & 962 & 9532.28 & 30776.69 & 1000 & 650000.00 \\
Cost of equipment for: Heat (1,000 VND) & 614 & 13534.62 & 36440.30 & 1000 & 500000.00 \\
Cost of equipment for: Lighting (1,000 VND) & 545 & 7270.13 & 16657.05 & 100 & 200000.00 \\
Corruption related variables & & & & & \\
Bribe (Yes=1) & 2646 & 0.43 & 0.50 & 0 & 1 \\
Bribe amount & 1134 & 10104.57 & 34731.27 & 300 & 1000000 \\
Provincial Competitiveness Index & 2647 & 53.66 & 4.37 & 48.96 & 60.86 \\
\hline
\end{tabular}

Source: compiled by author 
Table 1 presents the descriptive statistics of the variables used in the regressions. According to Table 1, measures for EFI are heterogenous and investments levels also vary based on type. While, on average, $37 \%$ of firms have invested in equipment for fire, only a quarter of firms have invested in heating technology improvements. Investments relating to lighting have been made by $21 \%$ of firms. In the context of respondent characteristics, $59 \%$ of respondents are male, while the average age of the respondents is approximately 46 . In addition, nearly $27 \%$ of respondents have attained a tertiary education, while only $17 \%$ of the respondents indicated that they have a good or average knowledge of the law. In terms of firm characteristics, on average, firms tend to employ around 16 workers while average firm age is 16.5 years. Around $90 \%$ of firms face high levels of competition, whereas $52 \%$ of firms reported they have positive R\&D investments. Nearly $63 \%$ of firms are household firms. Household businesses (HB) are responsible for almost $80 \%$ of the jobs in Vietnam and are of central importance in Vietnam's economic growth (Giang et al., 2016). Furthermore, nearly half of the firms reported having paid informal payments to public officials to get things done.

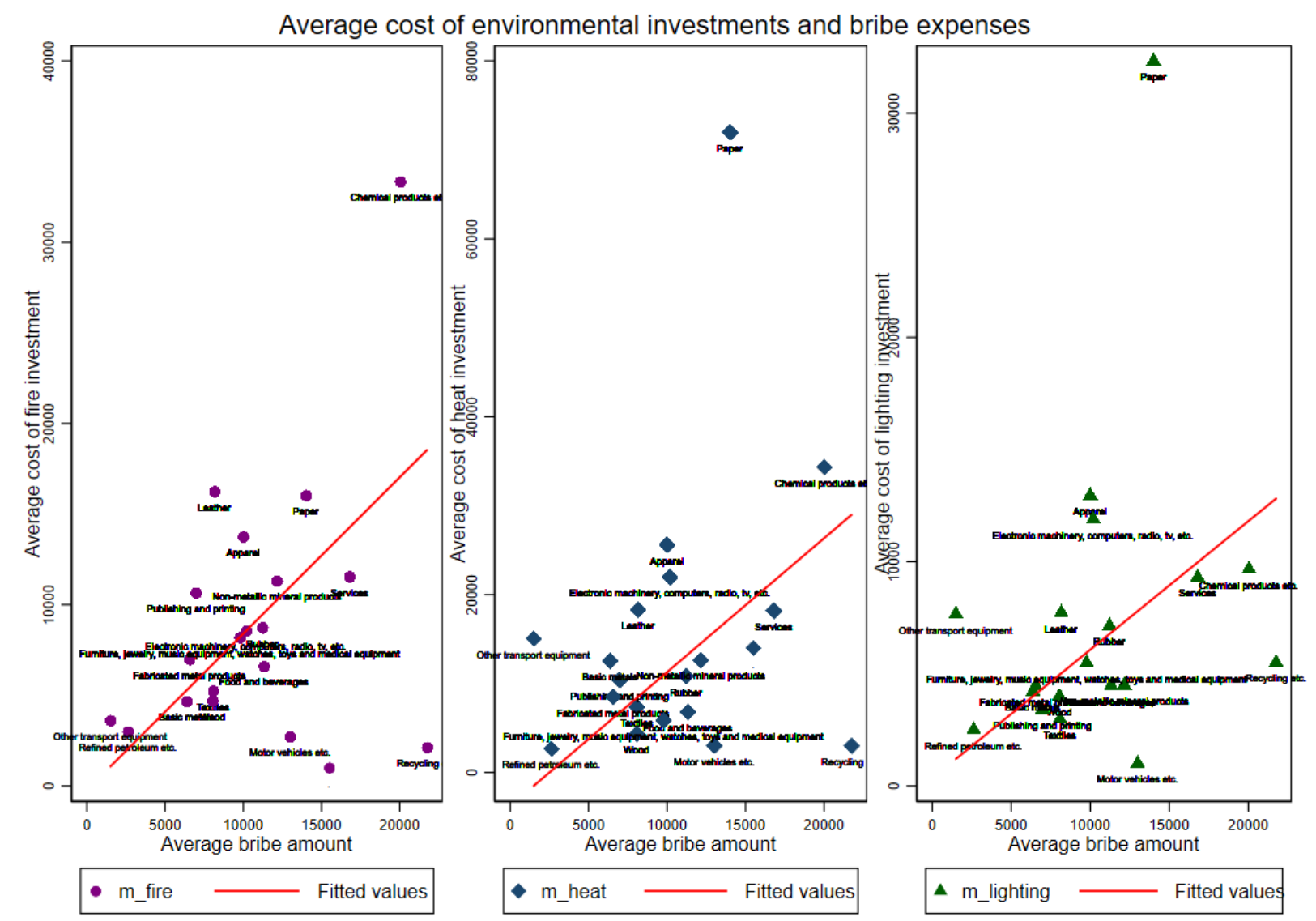

Figure 2: Cost of investments and bribe amount, by sector. Source: Compiled by authors based on the survey dataset used in empirical analysis.

To see pre-estimation correlations using data from Vietnamese small and medium-sized enterprises for 2015, we calculated the sectoral average cost of EFI measures and bribe amounts, as illustrated in Figure 1. The scatter plot seems to be in line with the literature showing that firms paying larger bribes tend to also have high EFI investment costs. 


\section{EMPIRICAL RESULTS}

Table 2 presents the marginal effects from the bivariate probit model estimations. According to the results, coefficients of the binary variable bribe are not statistically significant in Model $\mathrm{B}$ where firm propensity to invest in heating measures is the dependent variable. In all other models, however, bribe has statistically significant and positive coefficients. This means that any increase in the estimated probability of a bribe leads to a rise in the likelihood of EFI fire related investments and in the probability of obtaining a certificate for the registration of satisfaction of environmental standards. Similar interpretations could be made for Model C, where firm propensity to make lighting investments is the dependent variable. These results could imply that bribe has a positive impact on the likelihood of firms investing in EFI measures and this positive association is more likely to be related to obtaining a certificate for the registration of satisfaction of environmental standards. The positive association between bribe and the likelihood of investing in EFI is not entirely surprising, since through informal payments firms prefer to accelerate transactions in the inefficient public sector in Vietnam; however, this raises concerns related the business climate. Moreover, a firm has to be compliant with environmental regulations and have to invested in equipment that leads to cleaner production. Despite these efforts, monitoring officials could demand informal payments to issue production licences. Compliant firms could prefer to pay bribes to obtain certificates and production licences. 
Table 2: Bivariate probit marginal effects

\begin{tabular}{|c|c|c|c|c|c|c|}
\hline \multirow[b]{2}{*}{ Dep. Var. } & \multicolumn{2}{|c|}{ Model A } & \multicolumn{2}{|c|}{ Model B } & \multicolumn{2}{|c|}{ Model C } \\
\hline & $\begin{array}{c}\text { i_fire } \\
\text { (1) }\end{array}$ & $\begin{array}{l}\text { ESC } \\
(2)\end{array}$ & $\begin{array}{c}\text { i_heat } \\
\text { (3) }\end{array}$ & $\begin{array}{c}\text { ESC } \\
(4)\end{array}$ & $\begin{array}{c}\text { i_light } \\
(5)\end{array}$ & $\begin{array}{c}\text { ESC } \\
(6)\end{array}$ \\
\hline Bribe (dummy) & $\begin{array}{c}0.6160^{* * *} \\
(0.07)\end{array}$ & $\begin{array}{c}0.3867 * * * \\
(0.09)\end{array}$ & $\begin{array}{c}-0.0348 \\
(0.07)\end{array}$ & $\begin{array}{c}0.3765 * * * \\
(0.09)\end{array}$ & $\begin{array}{c}0.1955^{* * *} * \\
(0.07)\end{array}$ & $\begin{array}{c}0.3779 * * * \\
(0.09)\end{array}$ \\
\hline Male & $\begin{array}{c}-0.2666^{* * * *} \\
(0.06)\end{array}$ & $\begin{array}{c}-0.1450 * \\
(0.08)\end{array}$ & $\begin{array}{c}-0.0927 \\
(0.06)\end{array}$ & $\begin{array}{c}-0.1431 * \\
(0.08)\end{array}$ & $\begin{array}{c}-0.0825 \\
(0.06)\end{array}$ & $\begin{array}{c}-0.1437^{*} \\
(0.08)\end{array}$ \\
\hline Respondent age & $\begin{array}{c}0.0043 \\
(0.00)\end{array}$ & $\begin{array}{c}0.0011 \\
(0.00)\end{array}$ & $\begin{array}{c}0.0021 \\
(0.00)\end{array}$ & $\begin{array}{l}0.0008 \\
(0.00)\end{array}$ & $\begin{array}{l}0.0048 \\
(0.00)\end{array}$ & $\begin{array}{c}0.0006 \\
(0.00)\end{array}$ \\
\hline College & $\begin{array}{c}0.1986^{* *} \\
(0.08)\end{array}$ & $\begin{array}{c}0.2707^{* * *} \\
(0.09)\end{array}$ & $\begin{array}{l}0.1049 \\
(0.08)\end{array}$ & $\begin{array}{c}0.2722 * * * \\
(0.09)\end{array}$ & $\begin{array}{c}0.1241 \\
(0.08)\end{array}$ & $\begin{array}{c}0.2707 * * * \\
(0.09)\end{array}$ \\
\hline Law knowledge & $\begin{array}{c}0.1716^{* *} \\
(0.08)\end{array}$ & $\begin{array}{c}0.3369^{* * *} \\
(0.09)\end{array}$ & $\begin{array}{c}0.1274^{*} \\
(0.08)\end{array}$ & $\begin{array}{c}0.3411 * * * \\
(0.09)\end{array}$ & $\begin{array}{c}0.1100 \\
(0.08)\end{array}$ & $\begin{array}{c}0.3423 * * * \\
(0.09)\end{array}$ \\
\hline Firm size & $\begin{array}{c}0.0058^{* * *} \\
(0.00)\end{array}$ & $\begin{array}{c}0.0048^{* * *} \\
(0.00)\end{array}$ & $\begin{array}{c}0.0017^{* *} \\
(0.00)\end{array}$ & $\begin{array}{c}0.0048^{* * * *} \\
(0.00)\end{array}$ & $\begin{array}{l}0.0013 \\
(0.00)\end{array}$ & $\begin{array}{c}0.0048^{* * *} \\
(0.00)\end{array}$ \\
\hline Age & $\begin{array}{c}-0.0138 * * * \\
(0.00)\end{array}$ & $\begin{array}{c}0.0120^{* * *} \\
(0.00)\end{array}$ & $\begin{array}{c}-0.0028 \\
(0.00)\end{array}$ & $\begin{array}{c}0.0121 * * * \\
\quad(0.00)\end{array}$ & $\begin{array}{c}-0.0004 \\
(0.00)\end{array}$ & $\begin{array}{c}0.0122 * * * \\
\quad(0.00)\end{array}$ \\
\hline Household & $\begin{array}{c}-0.6687 * * * \\
(0.08)\end{array}$ & $\begin{array}{c}-0.9665^{* * *} \\
(0.10)\end{array}$ & $\begin{array}{c}-0.5386^{* * * *} \\
(0.08)\end{array}$ & $\begin{array}{c}-0.9669 * * * \\
(0.10)\end{array}$ & $\begin{array}{c}-0.6613^{* * *} \\
(0.08)\end{array}$ & $\begin{array}{c}-0.9653^{* * *} \\
(0.10)\end{array}$ \\
\hline Competition & $\begin{array}{c}0.5755^{* * *} \\
(0.12)\end{array}$ & $\begin{array}{c}0.0430 \\
(0.12)\end{array}$ & $\begin{array}{c}0.4134^{* * *} \\
(0.11)\end{array}$ & $\begin{array}{l}0.0597 \\
(0.12)\end{array}$ & $\begin{array}{c}0.3416 * * * \\
(0.11)\end{array}$ & $\begin{array}{c}0.0597 \\
(0.12)\end{array}$ \\
\hline$R \& D$ & $\begin{array}{c}0.3516^{* * *} \\
(0.07)\end{array}$ & $\begin{array}{c}-0.0393 \\
(0.08)\end{array}$ & $\begin{array}{c}-0.1239^{*} \\
(0.06)\end{array}$ & $\begin{array}{c}-0.0394 \\
(0.08)\end{array}$ & $\begin{array}{c}-0.0827 \\
(0.07)\end{array}$ & $\begin{array}{c}-0.0403 \\
(0.08)\end{array}$ \\
\hline Export & $\begin{array}{c}0.0423 \\
(0.13)\end{array}$ & $\begin{array}{c}0.2254^{*} \\
(0.12)\end{array}$ & $\begin{array}{c}-0.0480 \\
(0.11)\end{array}$ & $\begin{array}{c}0.2316^{* *} \\
(0.12)\end{array}$ & $\begin{array}{c}-0.0259 \\
(0.11)\end{array}$ & $\begin{array}{c}0.2328 * * \\
(0.12)\end{array}$ \\
\hline Debt ratio & $\begin{array}{c}0.2049 \\
(0.13)\end{array}$ & $\begin{array}{c}0.0654 \\
(0.12)\end{array}$ & $\begin{array}{c}0.2622 \\
(0.17)\end{array}$ & $\begin{array}{c}0.0672 \\
(0.12)\end{array}$ & $\begin{array}{c}0.2812 \\
(0.17)\end{array}$ & $\begin{array}{l}0.0707 \\
(0.12)\end{array}$ \\
\hline ROA & $\begin{array}{c}-0.0937 * * * \\
(0.04)\end{array}$ & $\begin{array}{c}-0.1006^{* * * *} \\
(0.04)\end{array}$ & $\begin{array}{c}0.0119 \\
(0.02)\end{array}$ & $\begin{array}{c}-0.1057^{* *} \\
(0.04)\end{array}$ & $\begin{array}{c}-0.0075 \\
(0.02)\end{array}$ & $\begin{array}{c}-0.1051^{* *} \\
(0.04)\end{array}$ \\
\hline Lack of capital & $\begin{array}{l}0.1167 \\
(0.08)\end{array}$ & $\begin{array}{l}0.0171 \\
(0.09)\end{array}$ & $\begin{array}{c}-0.0229 \\
(0.07)\end{array}$ & $\begin{array}{l}0.0169 \\
(0.09)\end{array}$ & $\begin{array}{c}-0.0713 \\
(0.08)\end{array}$ & $\begin{array}{l}0.0147 \\
(0.09)\end{array}$ \\
\hline PCI_score & $\begin{array}{c}-0.0559 * * * \\
(0.01)\end{array}$ & $\begin{array}{c}0.0184^{*} \\
(0.01)\end{array}$ & $\begin{array}{c}-0.0397 * * * \\
(0.01)\end{array}$ & $\begin{array}{c}0.0200 * * \\
(0.01)\end{array}$ & $\begin{array}{c}-0.0474 * * * \\
(0.01)\end{array}$ & $\begin{array}{c}0.0195 * * \\
(0.01)\end{array}$ \\
\hline Sector dummies & YES & YES & YES & YES & YES & YES \\
\hline Rho & \multicolumn{2}{|c|}{$0.2258(0.0523)^{* * *}$} & \multicolumn{2}{|c|}{$0.0985(0.049)^{* *}$} & \multicolumn{2}{|c|}{$0.0811(0.048)^{*}$} \\
\hline $\begin{array}{l}\text { No. of Obs. } \\
\text { AIC } \\
\text { BIC }\end{array}$ & $\begin{array}{l}2610 \\
3908 \\
4113\end{array}$ & $\begin{array}{l}2610 \\
3908 \\
4113\end{array}$ & $\begin{array}{l}2610 \\
4086 \\
4291\end{array}$ & $\begin{array}{l}2610 \\
4086 \\
4291 \\
\end{array}$ & $\begin{array}{l}2610 \\
3840 \\
4045\end{array}$ & $\begin{array}{l}2610 \\
3840 \\
4045 \\
\end{array}$ \\
\hline
\end{tabular}

Robust standard errors in parentheses $* * * \mathrm{p}<0.01, * * \mathrm{p}<0.05,{ }^{*} \mathrm{p}<0.1$.

Source: Compiled by author.

In terms of other explanatory variables, we found having a tertiary education and knowledge of the law has a positive effect on the likelihood of investing in EFI and obtaining an ESC. The former results are in line with the results of Zografakis et al. (2008), that people who have participated in education projects become more energy efficient and exhibit energy efficient behaviour and presents less energy-squandering behaviour. Accordingly, one could say that people who acquire more education and knowledge of the law as it relates to the consequences of energy inefficiencies and sustainability, would have a greater likelihood of investing in energy efficiency. Firm size has a positive impact on the likelihood of a firm investing in energy efficiency, and this is consistent with the results of Kostka et al. (2013). Being a household enterprise decreases the likelihood of being energy inefficient and obtaining an ESC. One explanation could be that these household enterprises might not feel the stringency of regulations as much as private companies, joint stock companies or limited companies. Given their huge influence on the economy and society as a whole, environmental regulations and energy efficient policies should be designed to target household enterprises. Another important finding is how competition increases the likelihood of investing in energy efficiency measures and obtaining an ESC. This is probably related to the fact that 
competitive firms tend to align their production plan with certain standards in environmental regulations. Exporting firms have a greater likelihood of obtaining an ESC but no significant relationship was found with the probability to invest in EFI.

On the other hand, Table 3 presents the results of the instrumental variable two stage least squares estimations. The relationship between bribe amount and the cost of energy efficiency measures, such as fire, heat and lighting, are all statistically significant and positive. This means that the greater the bribes paid to public officials, the greater the increase in costs of EFI investments. This positive association could also mean that bribes could make EFI investments costly and small and medium-sized enterprises may not sustain their efforts for cleaner production in the long term. Several explanations could be offered for this positive association; for example, corruption is positively related to the costs of energy efficiency investments. One possible reason would be that energy efficient investments may cause firms to alter their production system, for example, by stopping production of specific products while introducing new products. These processes may all require new permits; red tape and public officials may demand informal payments to get things done. Of course, besides the cost of new environmental investments, these informal payments add extra costs, and at each new inspection, the burden of the bribe may increase costs and that may discourage firms from installing new machinery. Eventually, firms tend to keep using old environmentally dangerous production systems, and negative externality will remain higher and social costs will rise. Therefore, corruption as a signal of institutional disfunction raises the cost of energy efficiency; hence, deterring firms from aiming towards sustainable production. Accordingly, one may say that corruption also increases the environmental and social cost of production. 
Table 3: Instrumental variable two stage least squares estimations

\begin{tabular}{|c|c|c|c|c|c|c|}
\hline \multirow[b]{2}{*}{ VARIABLES } & \multicolumn{2}{|c|}{ Model 1} & \multicolumn{2}{|c|}{ Model 2} & \multicolumn{2}{|c|}{ Model 3} \\
\hline & $\begin{array}{c}\text { first } \\
\text { Ln (bribe_a) }\end{array}$ & $\begin{array}{c}\text { second } \\
\text { Ln (cfire) }\end{array}$ & $\begin{array}{c}\text { first } \\
\text { Ln (bribe_a) }\end{array}$ & $\begin{array}{c}\text { second } \\
\text { Ln (cheat) }\end{array}$ & $\begin{array}{c}\text { first } \\
\text { Ln (bribe_a) }\end{array}$ & $\begin{array}{c}\text { Second } \\
\text { Ln (clighting) }\end{array}$ \\
\hline Ln (bribe_a) & & $\begin{array}{c}0.738 * * \\
(0.321)\end{array}$ & & $\begin{array}{c}0.915^{* *} \\
(0.370)\end{array}$ & & $\begin{array}{c}0.759 * * \\
(0.308)\end{array}$ \\
\hline Time_tax & $\begin{array}{c}0.0568 * * * \\
(0.0192)\end{array}$ & & & & & \\
\hline Contacts & & & $\begin{array}{l}0.0274 * * * \\
(0.00907)\end{array}$ & & & \\
\hline Average frequency of bribing & & & & & $\begin{array}{c}0.972 * * * \\
(0.292)\end{array}$ & \\
\hline Male & $\begin{array}{l}0.00813 \\
(0.0888)\end{array}$ & $\begin{array}{l}-0.0331 \\
(0.0840)\end{array}$ & $\begin{array}{r}-0.0307 \\
(0.172)\end{array}$ & $\begin{array}{l}-0.130 \\
(0.193)\end{array}$ & $\begin{array}{l}-0.155 \\
(0.134)\end{array}$ & $\begin{array}{l}0.0851 \\
(0.144)\end{array}$ \\
\hline Respondent age & $\begin{array}{l}-0.00433 \\
(0.00421)\end{array}$ & $\begin{array}{l}-0.00181 \\
(0.00418)\end{array}$ & $\begin{array}{c}0.00182 \\
(0.00757)\end{array}$ & $\begin{array}{l}0.000223 \\
(0.00849)\end{array}$ & $\begin{array}{c}0.00151 \\
(0.00618)\end{array}$ & $\begin{array}{l}-0.00769 \\
(0.00634)\end{array}$ \\
\hline College & $\begin{array}{c}0.130 \\
(0.104)\end{array}$ & $\begin{array}{l}0.0751 \\
(0.108)\end{array}$ & $\begin{array}{l}0.0815 \\
(0.187)\end{array}$ & $\begin{array}{l}0.382^{*} \\
(0.213)\end{array}$ & $\begin{array}{c}0.125 \\
(0.151)\end{array}$ & $\begin{array}{c}0.211 \\
(0.159)\end{array}$ \\
\hline Law knowledge & $\begin{array}{l}0.213 * * \\
(0.0946)\end{array}$ & $\begin{array}{c}0.338 * * * \\
(0.119)\end{array}$ & $\begin{array}{l}0.0944 \\
(0.176)\end{array}$ & $\begin{array}{c}0.253 \\
(0.202)\end{array}$ & $\begin{array}{c}0.197 \\
(0.139)\end{array}$ & $\begin{array}{l}0.285^{*} \\
(0.157)\end{array}$ \\
\hline Firm size & $\begin{array}{c}0.00396 * * * \\
(0.000799)\end{array}$ & $\begin{array}{c}0.00158 \\
(0.00149)\end{array}$ & $\begin{array}{c}0.00400^{* * * *} \\
(0.00142)\end{array}$ & $\begin{array}{l}0.00374 * \\
(0.00225)\end{array}$ & $\begin{array}{c}0.00474 * * * \\
(0.00126)\end{array}$ & $\begin{array}{l}0.00333^{*} \\
(0.00199)\end{array}$ \\
\hline Age & $\begin{array}{l}-0.00108 \\
(0.00556)\end{array}$ & $\begin{array}{l}-0.00845 \\
(0.00530)\end{array}$ & $\begin{array}{l}-0.0174 * * \\
(0.00852)\end{array}$ & $\begin{array}{l}-0.00280 \\
(0.0117)\end{array}$ & $\begin{array}{l}-0.0183 * * \\
(0.00730)\end{array}$ & $\begin{array}{c}0.00260 \\
(0.00915)\end{array}$ \\
\hline Household & $\begin{array}{c}-0.585^{* * *} \\
(0.118)\end{array}$ & $\begin{array}{c}0.311 \\
(0.223)\end{array}$ & $\begin{array}{c}-0.900 * * * \\
(0.225)\end{array}$ & $\begin{array}{c}0.480 \\
(0.412)\end{array}$ & $\begin{array}{c}-0.788 * * * \\
(0.182)\end{array}$ & $\begin{array}{l}0.571 * \\
(0.314)\end{array}$ \\
\hline Competition & $\begin{array}{l}-0.188 \\
(0.246)\end{array}$ & $\begin{array}{c}0.227 \\
(0.245)\end{array}$ & $\begin{array}{l}-0.442 \\
(0.352)\end{array}$ & $\begin{array}{l}-0.0225 \\
(0.432)\end{array}$ & $\begin{array}{l}-0.0536 \\
(0.306)\end{array}$ & $\begin{array}{l}-0.307 \\
(0.314)\end{array}$ \\
\hline$R \& D$ & $\begin{array}{l}-0.00151 \\
(0.0952)\end{array}$ & $\begin{array}{l}-0.0471 \\
(0.0902)\end{array}$ & $\begin{array}{c}0.251 \\
(0.182)\end{array}$ & $\begin{array}{l}-0.127 \\
(0.235)\end{array}$ & $\begin{array}{c}0.166 \\
(0.143)\end{array}$ & $\begin{array}{l}-0.284^{*} \\
(0.160)\end{array}$ \\
\hline Export & $\begin{array}{c}0.484 * * * \\
(0.124)\end{array}$ & $\begin{array}{l}-0.132 \\
(0.196)\end{array}$ & $\begin{array}{c}0.710 * * * \\
(0.217)\end{array}$ & $\begin{array}{l}-0.430 \\
(0.380)\end{array}$ & $\begin{array}{c}0.716^{* * * *} \\
(0.174)\end{array}$ & $\begin{array}{l}-0.280 \\
(0.290)\end{array}$ \\
\hline Debt ratio & $\begin{array}{l}0.228 * \\
(0.135)\end{array}$ & $\begin{array}{l}-0.109 \\
(0.151)\end{array}$ & $\begin{array}{c}1.659 * * * \\
(0.396)\end{array}$ & $\begin{array}{c}-1.660 * * \\
(0.796)\end{array}$ & $\begin{array}{l}0.571 * * \\
(0.263)\end{array}$ & $\begin{array}{l}-0.497 \\
(0.332)\end{array}$ \\
\hline ROA & $\begin{array}{c}-0.0829 * * * \\
(0.0317)\end{array}$ & $\begin{array}{c}0.0407 \\
(0.0412)\end{array}$ & $\begin{array}{l}-0.0394 \\
(0.0520)\end{array}$ & $\begin{array}{l}-0.0475 \\
(0.0611)\end{array}$ & $\begin{array}{l}-0.0708^{*} \\
(0.0386)\end{array}$ & $\begin{array}{c}0.0190 \\
(0.0456)\end{array}$ \\
\hline Lack of capital & $\begin{array}{c}-0.0144 \\
(0.109)\end{array}$ & $\begin{array}{l}-0.112 \\
(0.103)\end{array}$ & $\begin{array}{l}-0.0135 \\
(0.186)\end{array}$ & $\begin{array}{l}-0.108 \\
(0.208)\end{array}$ & $\begin{array}{l}-0.0638 \\
(0.155)\end{array}$ & $\begin{array}{c}0.00980 \\
(0.162)\end{array}$ \\
\hline PCI_score & $\begin{array}{c}0.0566 * * * \\
(0.0170)\end{array}$ & $\begin{array}{l}-0.00298 \\
(0.0231)\end{array}$ & $\begin{array}{c}0.0113 \\
(0.0269)\end{array}$ & $\begin{array}{l}-0.00337 \\
(0.0304)\end{array}$ & $\begin{array}{c}0.0292 \\
(0.0236)\end{array}$ & $\begin{array}{l}-0.0247 \\
(0.0267)\end{array}$ \\
\hline $\begin{array}{l}\text { Sector dummies } \\
\text { Constant }\end{array}$ & $\begin{array}{c}\text { YES } \\
5.664^{* * *} \\
(0.965)\end{array}$ & $\begin{array}{c}\text { YES } \\
1.986 \\
(2.159)\end{array}$ & $\begin{array}{c}\text { YES } \\
7.648^{* * *} \\
(1.458)\end{array}$ & $\begin{array}{c}\text { YES } \\
1.243 \\
(3.300)\end{array}$ & $\begin{array}{c}\mathrm{YES} \\
4.895^{* * *} \\
(1.336)\end{array}$ & $\begin{array}{c}\text { YES } \\
3.385 \\
(2.370)\end{array}$ \\
\hline $\begin{array}{l}\text { Observations } \\
\text { R-squared }\end{array}$ & $\begin{array}{c}680 \\
0.265 \\
\end{array}$ & $\begin{array}{c}680 \\
0.076 \\
\end{array}$ & $\begin{array}{c}251 \\
0.411 \\
\end{array}$ & $\begin{array}{c}251 \\
0.044 \\
\end{array}$ & $\begin{array}{c}354 \\
0.354 \\
\end{array}$ & $\begin{array}{c}354 \\
0.015 \\
\end{array}$ \\
\hline
\end{tabular}

\section{CONCLUSIONS}

In this paper, we empirically modelled the relationship between corruption and firms' energy efficiency investments. To date, previous studies have overlooked the role of the institutional setting, in particular, the effect of corruption on the adoption of energy efficiency technologies. This paper contributes to the literature on the barriers to energy efficiency 
investments by introducing the institutional setting, proxied by bribery paid to public officials and environmentally friendly investments, proxied by energy efficiency investments in several ways. First, by using the Vietnamese small and medium-sized enterprise survey, we shed new light on the determinants of energy efficiency investments in a developing country (Vietnam), which requires more attention regarding environmental issues. Second, through empirical testing we deepened our knowledge of the link between bribery and environmental investments at the firm level. To date, studies regarding this issue were limited to only theoretical contributions. Third, we show that country-specific institutional quality is equally important, or no less important than firm or industry characteristics in the adoption of energy efficient technologies and measures.

The tendency of firms to invest in energy efficiency and a certificate for the registration of satisfaction of environmental standards is examined using a bivariate probit framework, where the two intentions are modelled together. This paper found that bribery has a positive impact on the likelihood of investing in energy efficient equipment and obtaining a certificate for the registration of satisfaction of environmental standards. Consequently, bribery seems to have a grease the wheel effect on investing in energy efficiency mainly due to the abuse of power for obtaining a certificate. However, instrumental variable analysis revealed that bribes or informal payments to public officials indeed have a positive impact on the cost of energy efficiency investments. This means that bribery increases the cost of energy efficiency investments. Therefore, one can anticipate that firms may not be willing to invest in energy efficiency measures due to the increasing costs. Considering the results of the bivariate probit analysis, bribery pushes firms to invest in energy efficiency, whereas this hurts firms by increasing costs. Therefore, in the long run, one may expect that corruption may have a deterring effect on energy efficiency investments; hence, the sustainability of production.

This paper builds on literature on the factors affecting energy efficiency and highlights the understudied effect of institutional dysfunctionality (i.e. corruption) on the energy efficiency of firms. The findings of this paper suggest that increasing energy efficiency and sustainability require improvements in institutional quality through strengthening law enforcement against polluting firms and corruption. This paper has its own weaknesses. First, this research has been performed by using a dataset from Vietnam; hence, it is a singlecountry study. Vietnam, as a transition country in Southeast Asia has its own dynamics, specific social norms and business environment. Therefore, future studies should undertake similar work in other countries. Second, this paper is limited to cross-sectional firm-level data. Therefore, it may not capture time variant effects and changes in variables over time. Future research may extend this study by employing a longitudinal dataset to deepen our knowledge. 


\section{REFERENCES}

Aklin, M., Bayer, P., Harish, S.P. and Urpelainen, J., 2014. Who blames corruption for the poor enforcement of environmental laws? Survey evidence from Brazil. Environmental Economics and Policy Studies, 16(3), pp.241-262.

Ashyrov, G. (2020), "Role of managerial traits in firm-level corruption: evidence from Vietnam", Journal of Small Business and Enterprise Development, Vol. 27 No. 1, pp. $52-$ 72. https://doi.org/10.1108/JSBED-01-2019-0019.

Ashyrov, G., \& Masso, J. (2020). Does corruption affect local and foreign-owned companies differently? Evidence from the BEEPS survey. Post-Communist Economies, 32(3), 306329.

Becker, G.S., 1968. Crime and punishment: An economic approach. In The economic dimensions of crime (pp. 13-68). Palgrave Macmillan, London..

Bunse, K., Vodicka, M., Schönsleben, P., Brülhart, M. and Ernst, F.O., 2011. Integrating energy efficiency performance in production management-gap analysis between industrial needs and scientific literature. Journal of Cleaner Production, 19(6-7), pp.667679.

Cagno, E. and Trianni, A., 2013. Exploring drivers for energy efficiency within small-and medium-sized enterprises: first evidences from Italian manufacturing enterprises. Applied Energy, 104, pp.276-285.

Cole, M.A., 2007. Corruption, income and the environment: an empirical analysis. Ecological Economics, 62(3-4), pp.637-647.

Damania, R., Fredriksson, P.G. and List, J.A., 2003. Trade liberalization, corruption, and environmental policy formation: theory and evidence. Journal of environmental economics and management, 46(3), pp.490-512.

De Rosa, D., Gooroochurn, N. and Görg, H., 2015. Corruption and productivity: Firm-level evidence. Jahrbücher für Nationalökonomie und Statistik, 235(2), pp.115-138.

Dickel, P. and Graeff, P., 2018. Entrepreneurs' propensity for corruption: A vignette-based factorial survey. Journal of Business Research, 89, pp.77-86.

Dillard, J., Pullman, M.E., Loucks, E.S., Martens, M.L. and Cho, C.H., 2010. Engaging small-and medium-sized businesses in sustainability. Sustainability Accounting, Management and Policy Journal. 1(2), pp. 178-200, DOI: 10.1108/20408021011089239

Fan, P., Ouyang, Z., Nguyen, D.D., Nguyen, T.T.H., Park, H. and Chen, J., 2019. Urbanization, economic development, environmental and social changes in transitional economies: Vietnam after Doimoi. Landscape and urban planning, 187, pp.145-155.

Fisman, R. and Svensson, J., 2007. Are corruption and taxation really harmful to growth? Firm level evidence. Journal of development economics, 83(1), pp.63-75.

Fredriksson, P.G. and Svensson, J., 2003. Political instability, corruption and policy formation: the case of environmental policy. Journal of public economics, 87(7-8), pp.1383-1405.

Fredriksson, P.G., List, J.A. and Millimet, D.L., 2003. Bureaucratic corruption, environmental policy and inbound US FDI: theory and evidence. Journal of public Economics, 87(7-8), 
pp.1407-1430.

Fresner, J., Morea, F., Krenn, C., Uson, J.A. and Tomasi, F., 2017. Energy efficiency in small and medium enterprises: Lessons learned from 280 energy audits across Europe. Journal of Cleaner Production, 142, pp.1650-1660.

Gadenne, D.L., Kennedy, J. and McKeiver, C., 2009. An empirical study of environmental awareness and practices in SMEs. Journal of Business Ethics, 84(1), pp.45-63.

Galinato, G.I. and Chouinard, H.H., 2018. Strategic interaction and institutional quality determinants of environmental regulations. Resource and Energy Economics, 53, pp.114-132.

Gao, C.K., Wang, D., Cai, J.J. and Zhu, W.G., 2010. Scenario analysis on economic growth and environmental load in China. Procedia Environmental Sciences, 2, pp.1335-1343.

General Statistics Office of Vientnam [http://www.gso.gov.vn/default_en.aspx?tabid=775], accessed 15.01.2020

Giang, D.H., Xuan, P.T. and Hai, N.Q., 2016. Corruption risks in Vietnam's household business sector. Crime, Law and Social Change, 65(4-5), pp.395-422.

Gueorguiev, D. and Malesky, E., 2012. Foreign investment and bribery: a firm-level analysis of corruption in Vietnam. Journal of Asian Economics, 23(2), pp.111-129.

Hanif, I., Raza, S.M.F., Gago-de-Santos, P. and Abbas, Q., 2019. Fossil fuels, foreign direct investment, and economic growth have triggered $\mathrm{CO} 2$ emissions in emerging Asian economies: some empirical evidence. Energy, 171, pp.493-501. DOI: 10.1016/j.energy.2019.01.011

Harstad, B. and Svensson, J., 2011. Bribes, lobbying, and development. American Political Science Review, 105(1), pp.46-63.

Hrovatin, N., Dolšak, N. and Zorić, J., 2016. Factors impacting investments in energy efficiency and clean technologies: empirical evidence from Slovenian manufacturing firms. Journal of cleaner production, 127, pp.475-486.

International Energy Agency (2020). Data and statistics. [https://www.iea.org/data-andstatistics] accessed 15.01.2020

Kaufmann, D., 1997. Corruption: the facts. Foreign policy, pp.114-131.

Kostka, G., Moslener, U. and Andreas, J., 2013. Barriers to increasing energy efficiency: evidence from small-and medium-sized enterprises in China. Journal of Cleaner Production, 57, pp.59-68.

Kounetas, K. and Tsekouras, K., 2008. The energy efficiency paradox revisited through a partial observability approach. Energy Economics, 30(5), pp.2517-2536.

Luong, N.D., 2015. A critical review on energy efficiency and conservation policies and programs in Vietnam. Renewable and Sustainable Energy Reviews, 52, pp.623-634.

Mauro, P., 1995. Corruption and growth. The quarterly journal of economics, 110(3), pp.681712.

Mendoza, R.U., Lim, R.A. and Lopez, A.O., 2015. Grease or sand in the wheels of commerce? Firm level evidence on corruption and SMEs. Journal of International 
Development, 27(4), pp.415-439.

Méon, P. G., \& Sekkat, K. (2005). Does corruption grease or sand the wheels of growth?. Public choice, 122(1-2), 69-97.

Nguyen, N.A., Doan, Q.H., Nguyen, N.M. and Tran-Nam, B., 2016. The impact of petty corruption on firm innovation in Vietnam. Crime, Law and Social Change, 65(4-5), pp.377-394.

Nguyen, T.V., Ho, B.D., Le, C.Q. and Nguyen, H.V., 2016. Strategic and transactional costs of corruption: perspectives from Vietnamese firms. Crime, Law and Social Change, 65(4-5), pp.351-374.

OECD (2018) ASEAN SME Policy Index [https://www.oecd.org/investment/sme-policyindex-asean-2018-9789264305328-en.htm]

O'Toole, C.M. and Tarp, F., 2014. Corruption and the efficiency of capital investment in developing countries. Journal of International Development, 26(5), pp.567-597.

Pang, R., Zheng, D., Shi, M. and Zhang, X., 2019. Pollute first, control later? Exploring the economic threshold of effective environmental regulation in China's context. Journal of environmental management, 248, p.109275. DOI: 10.1016/j.envman.2019.109275

Parker, C.M., Redmond, J. and Simpson, M., 2009. A review of interventions to encourage SMEs to make environmental improvements. Environment and planning C: Government and policy, 27(2), pp.279-301.

Pellegrini, L. and Gerlagh, R., 2006. Corruption, democracy, and environmental policy: an empirical contribution to the debate. The Journal of Environment \& Development, 15(3), pp.332-354.

Rand, J. and Tarp, F., 2012. Firm-level corruption in Vietnam. Economic Development and Cultural Change, 60(3), pp.571-595.

Reinikka, R. and Svensson, J., 2006. Using micro-surveys to measure and explain corruption. World Development, 34(2), pp.359-370.

Ren, S., Li, X., Yuan, B., Li, D. and Chen, X., 2018. The effects of three types of environmental regulation on eco-efficiency: A cross-region analysis in China. Journal of cleaner production, 173 , pp.245-255.

Revell, A. and Blackburn, R., 2007. The business case for sustainability? An examination of small firms in the UK's construction and restaurant sectors. Business strategy and the environment, 16(6), pp.404-420.

Rohdin, P. and Thollander, P., 2006. Barriers to and driving forces for energy efficiency in the non-energy intensive manufacturing industry in Sweden. Energy, 31(12), pp.1836-1844.

Sheng, J., Zhou, W. and Zhang, S., 2019. The role of the intensity of environmental regulation and corruption in the employment of manufacturing enterprises: evidence from China. Journal of Cleaner Production, 219, pp.244-257.

Solnørdal, M.T. and Foss, L., 2018. Closing the energy efficiency gap-A systematic review of empirical articles on drivers to energy efficiency in manufacturing firms. Energies, 11(3), p.518.

Tarras-Wahlberg, N.H. and Nguyen, L.T., 2008. Environmental regulatory failure and metal 
contamination at the Giap Lai pyrite mine, Northern Vietnam. Journal of environmental management, 86(4), pp.712-720. DOI: 10.1016/j.jenvman.2006.12.012

Thollander, P. and Ottosson, M., 2008. An energy efficient Swedish pulp and paper industryexploring barriers to and driving forces for cost-effective energy efficiency investments. Energy Efficiency, 1(1), pp.21-34.

Trianni, A. and Cagno, E., 2012. Dealing with barriers to energy efficiency and SMEs: Some empirical evidences. Energy, 37(1), pp.494-504.

Trinh, B. and Quoc, B., 2017. Some problems on the sectoral structure, GDP growth and sustainability of Vietnam. Journal of Reviews on Global Economics, 6, pp.143-153.

Tromme, M., 2016. Corruption and corruption research in Vietnam-an overview. Crime, Law and Social Change, 65(4-5), pp.287-306.

UN SDG Knowledge Platform [https://sustainabledevelopment.un.org/sdg13], retrieved 13.12.2019

Van Vu, H., Tran, T.Q., Van Nguyen, T. and Lim, S., 2018. Corruption, types of corruption and firm financial performance: New evidence from a transitional economy. Journal of Business Ethics, 148(4), pp.847-858.

Vatn, A., 2020. Institutions for sustainability-Towards an expanded research program for ecological economics. Ecological Economics, 168, p.106507.

Vial, V. and Hanoteau, J., 2010. Corruption, manufacturing plant growth, and the Asian paradox: Indonesian evidence. World Development, 38(5), pp.693-705.

Wang, J., Yang, F., Zhang, X. and Zhou, Q., 2018. Barriers and drivers for enterprise energy efficiency: An exploratory study for industrial transfer in the Beijing-Tianjin-Hebei region. Journal of Cleaner Production, 200, pp.866-879.

Wang, N. and Chang, Y.C., 2014. The development of policy instruments in supporting lowcarbon governance in China. Renewable and Sustainable Energy Reviews, 35, pp.126135. DOI: 10.1016/j.rser.2014.03.021

Wellalage, N.H., Locke, S. and Samujh, H., 2019. Firm bribery and credit access: evidence from Indian SMEs. Small Business Economics, pp.1-22.

Williamson, O.E., 1985. The Economic Institutions of Capitalism, New York, NY.

Woods, N.D., 2008. The policy consequences of political corruption: Evidence from state environmental programs. Social Science Quarterly, 89(1), pp.258-271.

Yildirim, J. and Dal, S., 2016. Social transfers and labor force participation relation in Turkey: A bivariate probit analysis. Emerging Markets Finance and Trade, 52(7), pp.1515-1527.

Zografakis, N., Menegaki, A.N. and Tsagarakis, K.P., 2008. Effective education for energy efficiency. Energy Policy, 36(8), pp.3226-3232.

Zugravu, N., Millock, K., Duchene, G., 2008. The Factors Behind CO2 Emission Reductions in Transition Economies, FEEM Working Paper No 58.2008. 
Appendix 1. Definitions of variables used in descriptive tables and regression analysis

\begin{tabular}{|c|c|}
\hline Variable & Explanation \\
\hline \multicolumn{2}{|l|}{ Respondent characteristics } \\
\hline Male & $=1$ if gender of the respondent is male \\
\hline Respondent age & Age of the respondent. Continuous. \\
\hline College & $=1$ Respondent's education level if above secondary \\
\hline Law knowledge & $=1$ respondent reported 'good' and 'average' \\
\hline \multicolumn{2}{|l|}{ Firm characteristics } \\
\hline Firm size & Firm size. Based on number of employees. \\
\hline Age & Firm age. \\
\hline Household & $=1$ if firm is household enterprise \\
\hline Competition & $=1$ if firm has competition) \\
\hline $\mathrm{R} \& \mathrm{D}$ investment & $=1$ if firm has reported $R \& D$ investments) \\
\hline Export & $=1$ if firm reported positive exporting) \\
\hline Debt Ratio & Total (short and long) liabilities/total assets \\
\hline Return on assets (ROA) & Net profit/assets \\
\hline Shortage of capital & $\begin{array}{l}=1 \text { if firm reported shortage of capital/credit as major constraints to } \\
\text { the growth of the enterprise }\end{array}$ \\
\hline \multicolumn{2}{|l|}{ Firm environmental variables } \\
\hline Investments in equipment for: Fire & $=1$ if firm reported investments on fire \\
\hline Investments in equipment for: Heat & $=1$ if firm reported investments on heat) \\
\hline Investments in equipment for: Lighting & $=1$ if firm reported investments on lighting) \\
\hline Investments in equipment for: Pollution & $\begin{array}{l}=1 \text { if firm reported investments on air quality, noise, waste disposal, } \\
\text { water pollution, soil degradation/pollution) }\end{array}$ \\
\hline Env_esc & $\begin{array}{l}=1 \text { if firm has Certificate for registration of satisfaction of } \\
\text { environmental standards }\end{array}$ \\
\hline Cost of equipment for: Fire (1,000 VND) & Cost of investment for fire \\
\hline Cost of equipment for: Heat (1,000 VND) & Cost of investment for heat (energy efficiency) \\
\hline Cost of equipment for: Lighting (1,000 VND) & Cost of investment for light (energy efficiency) \\
\hline Cost of equipment for: Pollution & Cost of investment for cleaning pollution (clean technology) \\
\hline \multicolumn{2}{|l|}{ Corruption related variables } \\
\hline Bribe & $=1$ if firm reported paying informal payment or communications fee \\
\hline Bribe amount & $\begin{array}{l}\text { Continuous variable. Approximately how much did you pay in total in } \\
2014 \text { ? }\end{array}$ \\
\hline PCI & Vietnamese Provincial competitiveness Index (higher is better) \\
\hline
\end{tabular}

Source: compiled by author 


\section{KOKKUVÕTE}

\section{Kas korruptsioon pidurdab ettevõtete energiaefektiivsust? Vietnami näide}

Vietnam on hea näide arenevast riigist, kus on toimunud kiire majanduskasv, kuid energiaefektiivsus on endiselt madal. Energiaefektiivsusse tehtavad investeeringud on olulised nii keskkonna-, sotsiaal- kui majandusvaldkonna seisukohast ning valitsuse ja ettevõtete esindajad julgustavad ettevõtteid nendesse meetmetesse rohkem investeeriuma. Kuid paraku pole Vietnamis soovitud investeeringute taset saavutatud. Rahvusvahelises kirjanduses on uuritud ettevõtete energiaefektiivsuse investeeringute majanduslikke tegureid, kuid institutsionaalsele keskkonnale on vähe tähelepanu pööratud. Käesoleva artikli eesmärgiks on uurida, kuidas korruptsioon kui institutsionaalse nõrkuse indikaator on seotud ettevõtete energiaefektiivsusega. Artiklis kasutatakse 2015. a Vietnami väike- ja keskmise suurusega ettevõtete andmebaasi, mis sisaldab põhjalikku infot ettevõtete finants- ja tööturunäitajate, innovatsiooni ning investeeringute kohta. Binaarse probit-mudeli tulemused näitavad, et korruptsioon suurendab energiaefektiivsete investeeringute tegemise tõenäosust. Kuid kaheetapilise instrumentmuutuja mudeli abil saadud tulemused näitavad, et korruptsioon suurendab investeeringu maksumust. Seega, pikas perspektiivis võib korruptsioonil olla heidutav mõju ettevõtete energiaefektiivsuse investeeringutele. 